\title{
The Implementation of Islamic Business Ethical Theory in E-Commerce
}

\author{
Zuraidah Zuraidah $^{1 *}$, Esy Nur Aisyah ${ }^{1}$ \\ ${ }^{1}$ Universitas Islam Negeri Maulana Malik Ibrahim Malang, Indonesia \\ *Corresponding author.Email: zuraidah@akuntansi.uin-malang.ac.id
}

\begin{abstract}
Internet as a communicative medium eases people to do online trading business. The network connection is easily accessible to the community. There are problems in the transactions through social media when sellers commit fraud in transactions and mismatch the goods and/or services. In addition, the hidden defects in the selling goods can be the biggest modus operandi of online sellers, both intentional and unintentional. Based on the problems above, the authors are interested in analyzing the application of Islamic business ethics in the online sell and purchase transactions. The purpose of this study is to examine the implementation of business ethics in e-commerce, especially in the rapid development of e-commerce in Indonesia, and to find out the importance of managing ethical issues. The results show that e-commerce businesses in Indonesia recorded a sales volume growth of 71.5 million average visits per month in the first quarter of 2020 and increased to 93.4 million average visits per month in the second quarter of the same year. The decrease in the number of online fraud reports per year, in 2019 as many as 1,600 cases and in 2020 down to 650 cases. From these results, it is hoped that practitioners will be able to apply higher standards of business ethics in e-commerce activities to protect and maintain e-commerce industry for improving the welfare of Indonesian citizen.
\end{abstract}

Keywords: Business Ethical Theory, Islamic Business Ethics, E-commerce

\section{INTRODUCTION}

Nowadays, most of the social life aspects are connected to technology. Technological usage that uses Internet is the essential thing in everyday activities of Indonesian people. The technology and internet accommodate not only the communication, but also commercial transactions and trading activities both individually and among regions. Today business and economic sectors are fields that are influenced by them. In the development of technology, called the Industrial Revolution 4.0, the internet world becomes more important and the human mobility gets higher. As a result, all aspects and sectors have to give express and precise services. In industrial sector, for instance, producers must give fast and appropriate services for the customers satisfaction. Thus, e-commerce is one solution.

In 1998, e-commerce was known as a transaction conducted by buyers and sellers in various products electronically from one company to another by using computer as the media. The other opinion said that Electronic Commerce, further called E-Commerce, is a result of internet technological development. The definition of e-commerce is a business using the electronic technology relating the companies, customers, and society in electronic transactions. Therefore, the business principle in e-commerce is the paperless trading.

According to the statistical report about top 10 ecommerce in July 2020, the most visited e-commerce in Indonesia is Shopee that is in the first rank with 71.5 million clicks per month during the first quarter of 2020 [1]. Beside Shopee, users visited various ecommerce in Indonesia as stated in Figure 1.

There are problems in sell and purchase transactions through social media when sellers commit fraud in transactions and mismatch of goods and/or services. In addition, the risk of hidden defects in the goods being sold can be the biggest modus operandi of online sellers, whether it is done intentionally and unintentionally. Meanwhile in the 
pandemic condition, e-commerce must have an active role in assisting Micro-Business Units to grow. With many suggestions to work and study from home, it will be the alternative for traders to keep selling from their houses. Another benefit is that the unlimited business and sales scopes around the world that makes it more prospective. The sales growth in online platform also climbs higher during the pandemic situation.

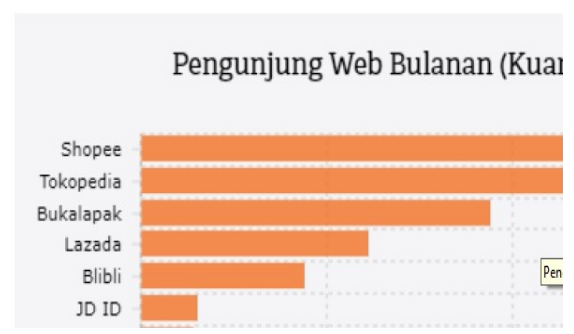

Figure 1 Monthly Web Visitor (1st Quarter of 2020) [1]

Moreover, the business performance does not only measure the collecting profit, but also concerning about moral commitment, service, quality, and social responsibility. Doing ethical action in business is the best long-termed business strategy. In general, the principles of ethical business are honesty, responsibility, transparancy, professional, trust, and equity.

Islamic business ethics is ethical norms based on the Quran and Hadith as the foundation for people in business. In Islamic teaching, Islamic business ethics demands and directs muslims to take actions in accordance with what is allowed and prohibited by Allah the Almighty, including to carry out the economic activities. Human beings are free to do them to improve their standard of living. The business ethics functions to help businessmen to solve moral problems. They should understand the ethics correctly to minimize the risks. The right principles will not harm anyone, even the society will receive more advantages from the sell and purchase activities [2]. This publication provides a snapshot of the potential and development of e-commerce businesses such as the number of e-commerce businesses, and the media.

Business requires ethics as a means as well as the basis so that the business leads to virtue. In this context, ethics is present as an instrument to restore human activities and everything related to business for a fundamental purpose of human life, namely happiness. Happiness is the main goal of human life. Business must be done happily and positively affects the people involved in the forms of welfare and prosperity. Therefore, Islamic business ethics is an important thing. It is the solution to various business problems [3].

This study uses a descriptive qualitative approach using a literature study. It will analyze sources, both qualitative and comparative of the previous studies, and articles on mass medias regarding the topic. The data are collected from books, journals and articles discussing Islamic Business Ethics.

\section{THE LITERATURE REVIEW}

\subsection{Theory of Business Ethics}

Many problems and cases in business world caused positive effects where there were more business ethical philosophers who tried to formulate and develop many business ethical theories. The ethics will not be understood if one puts aside moral values. Theory of business ethics also has moral value background. Here is the discussion of business ethical theory from various theories:

The first one is the Theory of Deontological Ethics. Deontology came from the Greek, deon (obligation or duty). Based on deontological ethics, an action is considered good because of judgment and justification or the action is acceptable. Someone conducts the obligation because it is his responsibility. In the business world, if there is a responsibility given to a person, he/she has an obligation to do it, if he/she does not want to disappoint the customers. For instance, giving a good service to customers, offering qualified goods and services that are comparable to the price, and so on. A buyer always needs satisfaction when he/she deals with a product [2] [3].

The second one is Theory of Theological Ethics. Theology came from the Greek, telos that means a purpose. Theological ethics measures the goodness or badness of an action based on the goals, or based on the consequences of that action. The activity is good if it aims to achieve something good or if the consequences are good and useful. From this theory, two studies emerged: 1) egoism; the theory views that moral behavior is considered good if it is more beneficial than detrimental for individuals who carry out moral actions, although they do not always have to ignore the welfare of others, 2) utiliatiarism; the theory is a derivative of the theological theory (consequentialist theory) where a business activity is good if it can provide benefits to the majority of society or consumers in a business context. It can also 
be said that good deeds are those that benefit many people [3] [4].

Next is Theory of Ethical and Human Rights. The approach of this theory is moral demands of a person, namely his/her rights, are taken seriously. In the theory of rights, it is discussed all about an individual rights and how they should be respected. In fact, it is stated that each person born on this earth has the rights and it deserved to be earned and fought for. One of the rights is getting a decent living (such as education, welfare, health service, etc). When a person is treated unfairly or harmed by a company, he deserves to claim his rights [3] [4].

There is also a Theory of Virtue. In this theory, a satisfaction concept is dominant, since everybody wants to be prioritized in fulfilling the interests he wants. Efforts to fulfill them often lead to selfishness [4].

The last one is Theory of Relative. It is stated that ethics is relative. Problems that arise in practice are self-centered (selfish), focusing on oneself, ignoring interactions with outsiders, no further consideration in making decision. All of them depend on one's criteria. In this theory, it is explained that the one's opinion is subjective. It means that if A thinks that something is the best, B might not have similar point of view, and so on. This is because everyone's views and thought can be different [4].

\subsection{Islamic Business Ethics}

Ethics, in general, is defined as a systematical effort by using ratio to interpret individual and social moral experiences, so that it can establish rules to control human behavior as well as meaningful values to be targeted in life [5].

The Islamic business ethics is a process and an effort to find out what is right and wrong. It is then continued by doing good regarding the provided products and company services so there will be parties interested in the company. The ethics cover learning the moral qualities of organizational policies, general concepts and standards for moral conduct in business, behave responsibly and morally. This means that Islamic business ethics is a moral habit or culture related to the business activities of a company. So it can be concluded that the Islamic business ethics is a set of values about good and bad, right and wrong, and halal and haram in the business world based on the principles of morality in accordance with sharia [5].
The characteristics of ethical standard in Islamic business are: 1) considering consequences for human welfare; and 2) upholding law and justice consistently, consequently, and faithfully in line to the principles of truth, civility, and dignity [6].

\subsection{The Principles of Business Ethics Based on the Quran}

There are five basic principles of Islamic ethics. The first principle is unity. In this case, the unity is reflected to the tauhid concept that combines all aspects of Muslim life in economics, politics, and social aspects. It means, Islam offers an integration of all aspects to form a unity. Based on this point of view, ethics and business are combined, both vertically and horizontally, to form an essential equality in the Islamic system [5] [7].

The second principle is equilibrium or fairness. Islam strongly recommends doing fairness in business, and prohibits cheating or being wrongful. Cheating in business is a sign of a destruction, because the key to business success is trust. The Quran orders Muslims to measure and weigh in a right way and forbids the cheating by reducing the measurement or weight. In Surah al-Isra: 35, Allah the Almighty says, "And give full measure when you measure, and weigh with an even balance. That is the best (way) and best in result" [6].

The next principle is free will. Freedom is an important part in Islamic business ethical values, but it should not risks to the collective interests. The individual attentiveness should be widely opened. Unlimited income encourages people to actively work with all their potential. The human tendency to continuously fulfill unlimited personal needs is controlled by the obligation of each individual to the surrounding community through zakat, infaq and charity [6] [7].

The fourth one is responsibility. Limitless freedom is something that is impossible for humans, because it does not require responsibility and accountability to meet the demands of fairness and unity. They need to be responsible for their actions logically. It sets limits on what humans are free to do by being responsible for everything they do [5] [7].

The last principle is truth, goodness and honesty. In this context, it either means the truth versus falsity or two elements of benevolence and honesty. In the business context, the truth means a proper intention, attitude, and behavior involving the transaction 
process, searching process or getting development commodities, even the process of gaining or setting profit. With this principle, the Islamic business ethics cares and prevent to possibilities of loss of one of the parties conducting a transaction, cooperation or agreement in the business [5] [6].

\subsection{Definition of E-Commerce}

There are many definitions of e-commerce stated by the experts. Baum defines it as a dynamic set of technologies, applications, and business process that link enterprises, consumers, and communities through electronic transactions and electronic exchange of goods, services, and information. Laudon \& Laudon defines it as a process of selling and buying products electronically from one company to the customers using computer as the business transactional media [8].

Kalakota and Whinston states that e-commerce can be viewed in 4 (four) perspectives; a) communication perspective, e-commerce is the delivery process of goods, services, information, or payment through computer network or other electronic equipments; b) business process perspective, e-commerce is an automatic technological application for business transactions and work flow; c) service perspective, e-commerce is a media to meet the interests of companies, consumers, and management to cut the service costs, improve the items quality, and increase the speed of delivery services; and d) online perspective, ecommerce provides the ability to buy and sell goods and information via the internet and other online means [9].

\subsection{Types of E-Commerce}

E-commerce activities cover many things. To distinguish it, e-commerce is divided into 2 (two) based on its characteristics. First, Business to Business (B2B), its characteristics are; a) trading partners already know each other and there has been a long-standing relationship between them; b) data exchange is regularly conducted with a mutually agreed data format; c) one of the players does not have to wait for their other partner to send the data; and d) the common model used is peer-to-peer in which the processing intelligence can be distributed to both business players [8]

Second, Business to Consumers, its characteristics are: a) being open to the public where information is shared publicly; b) the implemented services are also general, so that they can be used by many people; c) services are used on request; and d) client-server approach is often used [8].

\subsection{The Valid Laws and Regulations in Indonesia}

In the legal aspect, Indonesia currently has legal instruments that regulate electronic transactions, namely Law No. 11 of 2008 concerning the Electronic Information and Transaction Law (UUITE) which includes, among others, regulating efforts to protect the public in electronic transactions. In addition, Indonesia also has Law No. 7 of 2014 concerning trading which specifically regulates electronic commerce [8].

According to the regulations, all business actors in electronic commerce are obligated to register and fulfill the technical provisions of the relevant agencies. Each must have and declare the business ethics (business conduct or code of practices). Business actors are prohibited from requiring consumers to pay for products sent without prior agreement (inertia selling). Information or electronic documents can be used as evidence. Electronic information or document has the same legal force value as an authentic deed. Regarding on the electronic contracts, electronic trading contracts are valid when there is an agreement between the parties. The contracts must at least contain the identities of the parties, agreed specifications of goods or services, legality of goods and/or services, value or trade transactions, terms and conditions of payment, operational procedures for delivery of goods and/or services, and procedures for returning goods and/or if they occur mismatch. If there is a dispute related to trade transactions through an electronic system, the person or business entity that is experiencing the dispute can resolve it through the court or through other resolution mechanism [9].

Several issues are cited in the Law No.7 of 2014. First, every business actor is prohibited to trade goods and/or services by using electronic system that is not in accordance with the data and/or information; Second, the usage of electronic system must comply with provisions stipulated in the Law on Information and Electronic Transactions; and Third, the data and/or information should contain: a) identity and legality of the business actors as producers or distribution business actors; b) technical requirements of the goods offered; c) technical requirements or qualifications of services offered; d) price and 
method of payment for goods and/or services; and (e) how to deliver goods [4] [8].

Every business player who trades goods and/or services using an electronic system that does not give complete and valid data and/or information will be given an administrative sanction in the form of license revocation. Those who trade goods and/or services using and electronic system that is not in accordance with the data and/or information as referred to in the Article 65 Paragraph (2) will be sentenced to a maximum 12 years imprisonment and/or a maximum fine of IDR 12,000,000,000 (twelve billion rupiahs) [8].

To implement the mandate of Law No.11 of 2008, the government through the Ministry of Communication and Information has issued the following Government Regulations and Circular Letters.

First, Government Regulation of the Republic of Indonesia No.82 of 2012 concerning on the implementation of electronic systems and transactions. It regulates: a) the Implementation of Electronic System; b) the Application of Electronic Agency; c) the Adminstration of Electronic Transaction; d) the Electronic Signature; e) the Realization of Electronic Certification; f) the Reliability Certification Institution; and g) the Domain Name Management [8].

In relation to ethical issue, this regulation has regulated the obligation of electronic system operators to enter into standard service agreements with customers, confidentiality agreement and utilization of customer and transaction data. Electronic system operators for public services are required to implement acceptable and accountable administration. The administration presents procedures or instructions in the Electronic System Operation that are documented and/or announced in language, information, or symbols that are understood by all parties.

Second, the Regulation of the Minister of Communication and Information of the Republic of Indonesia No. 36 of 2014 concerning Procedures for Registration of Electronic System Operators. This regulation involves registration obligations and procedures for electronic system operators which include: a) portal, site, or online application via the internet that is used to facilitate the offer and/or trade of goods and/or services; b) an electronic system in which there are online payment facilities and/or other financial transactions through a data communication network or the internet; c) an electronic system used to process electronic information that contains or requires a deposit of funds or something that is equivalent to fund; d) an electronic system used to process or store data related to facilities for customer data in the operational activities to serve the public related to financial and trading transaction activities; and e) an electronic system used for delivery of paid digital materials through the data network either by downloading the portal/site, sending via email, or through other applications to the user's device. Electronic system operators must use Indonesian high-level domain names for website electronic systems [8].

\section{DISCUSSION}

The role of business ethics in e-commerce has a significant effect because it is the major support to develop a company. Without any ethics, the business will not grow or maintain and neither run well. It is also able to solve the existing problems. Ethics will resolve them without hurting others. The ethics teach businessmen and consumers to see the right and the wrong things. It also creates the special comfort for buyers when they are making transaction through websites. In good e-commerce trading, we should have ethics and social responsibility concerning on the functions [10].

The influence of business ethics in e-commerce is enormous because the development of technology in this age is so fast. Trading is increasingly accessible anywhere and wider. In the organizational aspect, business ethics can make each other feel comfortable and not jealous of what they have and make competition better and less fraudulent. They can establish good cooperation between producers and consumers [6]. With this business ethics, producers can see whether consumers are honest or lying in buying their products or services. Producers must also able to find out whether consumers can cooperate in transactions or not. On the other hand, producers may commit fraud, for example when consumers have paid for the goods that have been selected and have transferred the price, but the producer does not send them [9].

E-commerce businesses in Indonesia recorded the growth of sales volume with more people who do the physical distancing in the pandemic of Covid-19. The government also considers about the e-commerce sector as one of the solutions for solving the tax deficit as the result of economic slowdown. It is 
proven by the high increase of users in e-commerce application [1].

Business ethics or morals have very strong characteristics in our life. It is closely related to things that have a major impact on the life and wellbeing of individuals or groups. Trust each other in a cooperation will give a great influence to the reputation of a company, both in micro and macro environments. It will not give profit sooner, but it becomes the long-term investment for the entire elements in the business circle [11]. Therefore, the business ethics is very important. Figure 2 describes that there is a significant decrease of reports regarding e-commerce problems. It means that, by the time, Indonesian people gradually realizes that doing fair and good transactions are necessary for the improvement of life quality.

\section{Kloudal remlipudil Uillile Dilapor}

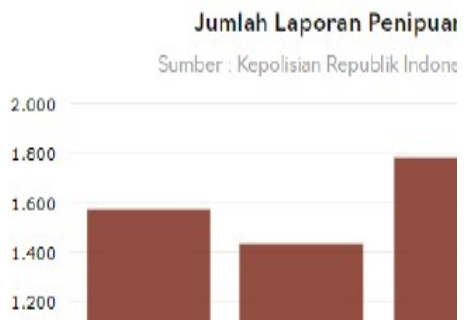

Figure 2 The Numbers of Online Cheating Report per Year

The Indonesian Ministry of Trade and Ministry of Communication and Information are the government's technical units that directly manage, control, monitor, and encourage the development of e-commerce industries in Indonesia. The laws and regulations above show that the Indonesian government seriously makes a set of regulations to build a healthy environment with the law guarantee and to protect the Indonesian e-commerce industries, both producers and consumers for growing the ecommerce industries to all Indonesian people's welfare.

\section{CONCLUSION}

Indonesian government greatly supports the development of Indonesian e-commerce industries. It is proven by publishing sets of laws, government and minister's regulations that involve the Ministry of Trade, Ministry of Information and Informatics, and other relevant state agencies. E-commerce improves well-being and support the digital industrial and national economic growths. The continuous improvement of regulations, rules and code of conduct in countries and companies are improved to give the better law guarantee and support the Indonesian e-commerce sectors. The ethic problems generally relate to ethics of honesty, responsibility, and moral awareness. However, the development of Standard Operation Procedure (SOP) in the process of e-commerce transaction is getting significant. Hopefully, all parties will support the improvement of e-commerce business for Indonesian people's welfare by obeying the rules. Islam through business ethics wants to frame as well as create good and conducive business practices in the current digital business era, so that business activities do not oppress other parties and can have positive impacts and results for all parties.

\section{AUTHORS' CONTRIBUTIONS}

This research contributes to the present conditions displayed through literature observations, documents, interviews with experts (lecturers who teach Islamic ethics courses), and FDG (Forum Group Discussion) so that the data collected is more accurate.

\section{REFERENCES}

[1] M. C. Dinisari, "E-commerce Dorong Perekonomian Indonesia, selama Pandemi Covid-19, https://ekonomi.bisnis.com/read/20200417/12/1 228750/ e-commerce-dorong-perekonomianindonesia-selama-pandemi-covid-19, Accessed on August 10, 2021.

[2] Muhammad Djakfar, Etika Bisnis: Menangkap Spirit Ajaran Langit dan Pesan Moral Ajaran Bumi, Penebar Plus, Jakarta, 2012, p.30

[3] A. Zakaria, Etika Bisnis Islam. Jakarta: Penerbit Ibnu Azka, 2012.

[4] Disfa, 2019. Etika Bisnis Islam: Sebuah Kajian Komparatif. Journal of Baabu Al-Ilmi 4(1) (2019) 36-58. DOI: http://dx.doi.org/10.29300/ba.v4i1.1852

[5] Abdul Aziz, Etika Bisnis Perspektif Islam, Bandung: Alfabeta, 2013

[6] H. Hidayatullah, Etika Bisnis Dalam Perspektif Al Qur'an: Upaya Membangun Bisnis yang Islami untuk Menghadapi Tantangan Bisnis di Masa Depan, Prosiding Seminas Competitive Advantage, 1(2) (2012). Retrieved from http://www.journal.unipdu.ac.id/index.php/semi nas/article/view/112

[7] F. Amalia, Etika Bisnis Islam: Konsep dan Implementasi pada Pelaku Usaha Kecil. Al- 
Iqtishad: Jurnal Ilmu Ekonomi Syariah, 6(1) (2014) 133-142. DOI: 10.15408/aiq.v6i1.1373

[8] I. N. Y. Maulana, Payung Hukum Perdagangan Elektronik (E-Commerce) dalam Tata Hukum Indonesia,

http://www.academia.edu/32759337/PAYUNG _HUKUM_PERDAGANGAN_ELEKTRONIK E-COMMERCE_DALAM_TATA_HUKUM

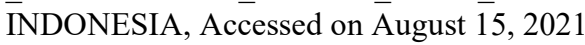

[9] M. Husaini, Bisnis E-Commerce dalam Perspektif Islam, Jurnal Ilmu Dakwah dan Pengembangan Komunitas 9(2) (2014) 186-200
[10] F. Amalia, Implementasi Etika Bisnis Islam Pada Pedagang di Bazar Madinah Depok, Prosiding Seminas Competitive Advantage 1(2) (2012). Retrieved from http://www.journal.unipdu.ac.id/index.php/semi nas/article/ view/134

[11] D. Hidayat, F. F. Hasib, Pencapaian Maslahah Melalui Etika Bisnis Islam: Studi Kasus Restoran Mie Akhirat, Jurnal Ekonomi Syariah: Teori dan Terapan 2(11) (2015) 912-927. DOI: http://dx.doi.org/10.20473/vol2iss201511pp912927 